Article history

Received Pebruary 28, 2018

Accepted July 1, 2018

\title{
PENERAPAN ALGORITMA GENETIKA MENGGUNAKAN METODE SELEKSI ROULETTE WHEEL PADA OPTIMASI PENENTUAN KOMPOSISI BAHAN PAKAN AYAM BROILER
}

\author{
Iqbal Fairus Zamani ${ }^{1)}$, Galih Wasis Wicaksono ${ }^{2)}$ Agus Eko Minarno ${ }^{3)}$ \\ 1,2,3 Teknik Informatika Universitas Muhammadiyah Malang \\ Email : fair.cuun92@gmail.com ${ }^{1)}$,galih.w.w@umm.ac.id ${ }^{2)}$, aguseko@umm.ac.id ${ }^{3)}$
}

\begin{abstract}
Along with many various human activity to fulfill the food nutritional in take vegetable nutrition and animal nutrition must be fulfilled. Animal nutrition is a needs that aften consumed by many people and one of those is broiler chicken. Broiler chicken is a livestuck chicken that easily produce, so there are so many broiler chicken farm that we could see in many place. But there are some problem that occur in most broiler breeders such as the composition of food ingredients and high ration costs. To fulfill the right composition of ingredients with minimum cost, researchers offer a solution by using genetic algorithm in deter mining the composition of broiler food ingredients. This aplication uses 50 ingredients of broiler chicken livestock along with nutrition. This study used roulette wheel methods. The result of this study obtained optimum parameters with population size of 400, various generation of 350 and pc 0.1 and pm 0.8 combinations of 10 times test. This result is a composition of broiler food ingredients that meet the nutritional needs with minimal cost.
\end{abstract}

Keywords: Genetic Algorithms, Broilers, Composition of feed ingredients

\begin{abstract}
Abstrak
Seiring dengan aktivitas manusia yang beragam untuk menjaga terpenuhinya asupan gizi pada makanan maka kebutuhan nabati dan hewani harus terpenuhi. Kebutuhan pangan hewani merupakan kebutuhan yang sering dikonsumsi oleh banyak orang dan salah satunya adalah ayam broiler. Ayam broiler merupakan hewan ternak yang mudah untuk diproduksi, maka dari itu banyak ternak ayam broiler yang kita jumpai diberbagai tempat. Namun ada beberapa permasalahan yang terjadi pada kebanyakan peternak ayam broiler yaitu mengenai komposisi bahan pakan dan biaya ransum ternak yang tinggi. Maka untuk memenuhi komposisi bahan yang tepat dengan biaya minimal peneliti menawarkan salah satu solusi menggunakan algoritma genetika dalam penentuan komposisi bahan pakan ternak ayam broiler. penerapan ini menggunakan data 50 bahan pakan ternak ayam broiler beserta nutrisinya metode yang digunnakan adalah metode roulette wheel. Dari hasil pengujian diperoleh parameter optimal dengan ukuran populasi 400 , banyak generasi 350 dan kombinasi pc 0.1 dan pm 0.8 dengan pengujian sebanyak 10 kali. Hasil ini merupakan komposisi bahan pakan ternak ayam broiler yang memenuhi kebutuhan nutrisi dengan biaya yang minimal.
\end{abstract}

Kata kunci: Algoritma Genetika, Ayam Broiler, Komposisi Bahan Pakan

\section{PENDAhuluan}

Latar Belakang

Pada era sekarang ini dengan pesatnya perkembangan teknologi dan meningkatnya jumlah penduduk, maka tingkat kesadaran masyarakat akan kebutuhan protein hewani makin meningkat. Bagaimana tidak kesibukan yang menyelimuti keseharian masyarakat sangat rasional bila masyarakat sekarang lebih cerdas dalam memenuhi kebutuhan gizi salah satunya adalah memilih makanan ternak sebagai menu makanan yang dirasa sangatlah mudah dalam 
penyajiaannya dan dinilai cukup dalam memenuhi nutrisi dalam tubuh.

Ayam broiler adalah ayam ras yang mempunyai kemampuan untuk tumbuh cepat sehingga dapat menghasilkan daging dalam waktu relatif singkat (5-7 minggu). Ayam broiler mempunyai peranan yang penting sebagai sumber protein hewani asal ternak. Dalam pemeliharaan ternak ayam broiler dipengaruhi oleh beberapa faktor agar ternak yang dihasilkan memiliki kualitas yang baik. Salah satu faktor yang dapat meningkatkan kualitas ternak ayam broiler yaitu pada pakan ternak yang diberikan.

Pakan ternak (ransum) menempati posisi penting pada usaha peternakan. Dalam sudut pandang ekonomi, biaya untuk pembelian ransum ternak merupakan biaya tertinggi dalam usaha peternakan, sehingga biaya tersebut harus ditekan serendah mungkin untuk memaksimalkan pendapatan. Tingginya pertumbuhan industri ternak juga akan meningkatkan kebutuhan ransum ternak di Indonesia. Para pelaku usaha peternakan membutuhkan teknik pemberian bahan ransum yang efesien untuk menyiasati tingginya biaya dalam membeli bahan ransum. Ternak memerlukan nutrisi (karbohidrat, lemak, protein, dan lain-lain) untuk menunjang hidupnya dan meningkatkan produk yang dihasilkan, seperti daging, susu, maupun telur. Kebutuhan nutrisi itu dipenuhi dari berbagai jenis bahan ransum (jagung, dedak padi, bungkil kedelai, dan lain-lain) yang dicampurkan menjadi satu dalam komposisi yang tepat(Andi. 2011).

Algoritma Genetika (lebih sering disebut Genetic Algorithm yang disingkat menjadi GA) merupakan teknik pencarian yang dilakukan sekaligus atas sejumlah solusi yang mungkin.( Indrianingsih. 2010) Algoritma ini memiliki kehandalan dalam menghasilkan output optimal yang dapat dimanfaatkan untuk memecahkan masalah dengan memanfaatkan perangkat lunak. Implementasinya diawali dengan inisialisasi yaitu pembangkitan solusi secara acak, reproduksi, evaluasi dan diakhiri dengan proses seleksi individu terbaik sebagai solusi terbaik.

Hasil dari menerapkan algoritma genetika yaitu nilai komposisi bahan pakan optimal yang dapat digunakan oleh para peternak untuk meningkatkan kualitas hasil ternaknya. Optimal yang dimaksud adalah terpenuhinya kebutuhan nutrisi ayam broiler namun dengan biaya pembelian pakan yang se-minimal mungkin.

Berdasarkan latar belakang diatas, dengan memanfaatkan teknologi dan ilmu pengetahuan, maka penulis memiliki ide untuk menerapkan GA dalam menentukan komposisi pakan ternak ayam broiler dengan judul "Penerapan Algoritma Genetika Menggunakan Metode Seleksi Roulette Wheel Pada Optimasi Penentuan Komposisi Bahan Pakan Ayam Broiler". Selain dari pada itu peneliti bertujuan menerapkan metode Algoritma Genetika seleksi Roulette wheel dalam mengoptimasi komposisi pakan ternak ayam broiler dan mengetahui hasil dari nilai yang tepat untuk optimasi komposisi pakan ternak ayam broiler.

\section{METODOLOGI PENELITIAN}

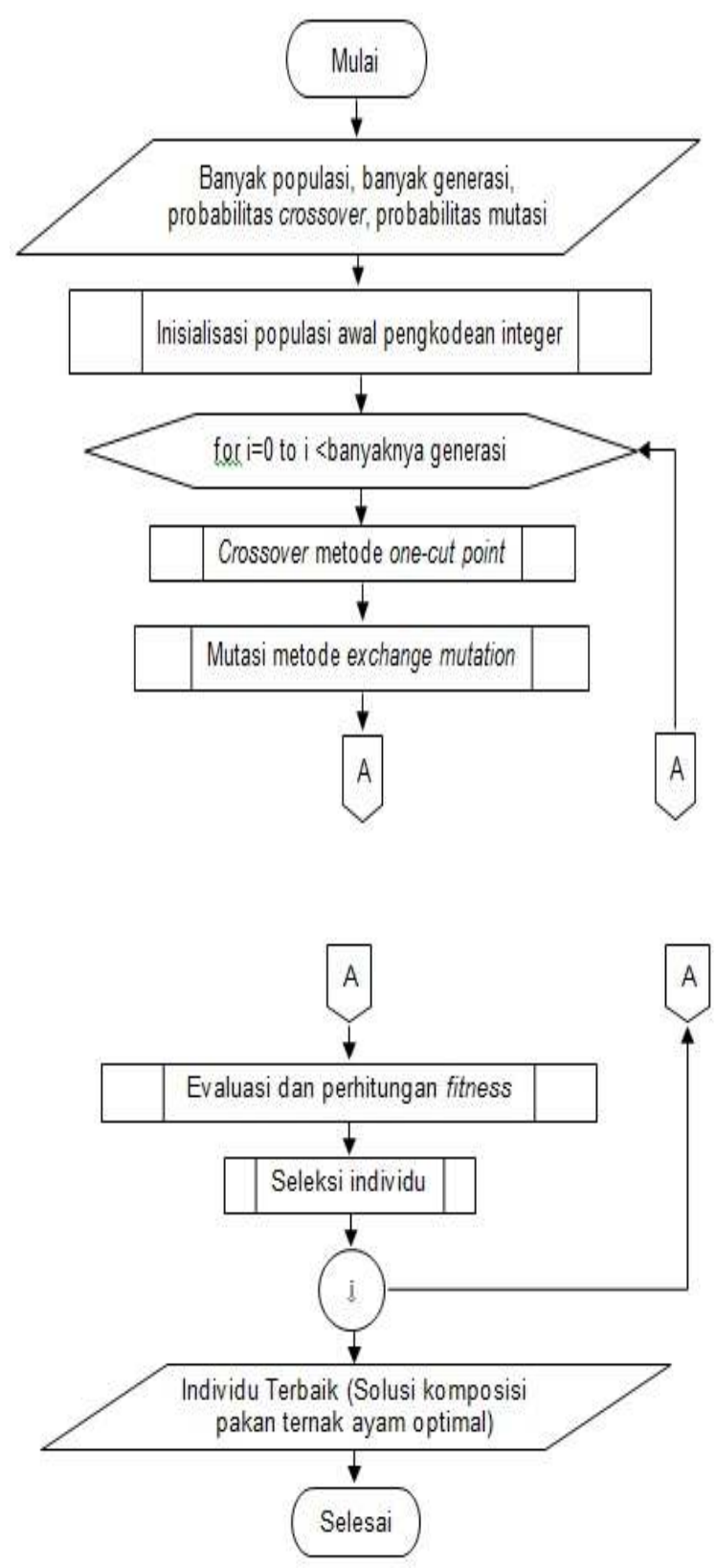

Gambar 1. Alur dari kerja algoritma genetika 
Dari gambar diatas menunjukkan bagaimana kerja dari algoritm genetika dalam permasalahan penentuan komposisi bahan pakan ayam broiler. Pada tahapan ini diperlukan data berupa 50 bahan pakan serta kandungan nutrisi, kemampuan konsumsi perhari dan kebutuhan nutrisi ayam broiler

Tabel 1. Konsumsi Pakan Ayam

\begin{tabular}{|c|c|c|}
\hline NO. & Fase Ayam & $\begin{array}{c}\text { Kemampuan } \\
\text { / hari }\end{array}$ \\
\hline 1 & Starter $(0-3 \mathrm{mg})$ & $44 \mathrm{gr}$ \\
\hline 2 & Finisher $(3-6 \mathrm{mg})$ & $162 \mathrm{gr}$ \\
\hline
\end{tabular}

Tabel 2. Kebutuhan Nutrisi Ayam Broiler

\begin{tabular}{|c|c|c|c|c|c|}
\hline $\begin{array}{c}\text { Periode } \\
\text { Umur }\end{array}$ & EM & PK & SK & Ca & P \\
\cline { 2 - 6 } & Kkal & $\mathbf{\%}$ & $\mathbf{\%}$ & $\mathbf{\%}$ & $\mathbf{\%}$ \\
\hline $\begin{array}{c}\text { Starter } \\
(0-3 \mathrm{mg})\end{array}$ & 3000 & 23 & 5 & 1 & 0.5 \\
\hline $\begin{array}{c}\text { Finisher } \\
(3-6 \mathrm{mg})\end{array}$ & 3100 & 20 & 5 & 1 & 0.8 \\
\hline
\end{tabular}

Inisialisasi, proses inisialisasi merupakan proses pembangkitan kromosom sebanyak jumlah populasi awal yang telah ditentukan. Berikut langkah-langkah pembangkitan populasi awal :

1. Menentukan jumlah populasi.

2. Lakukan proses inisialisasi kromosom sebanyak populasi awal.

a. Menentukan panjang kromosom individu sesuai dengan komposisi bahan pakan yang dipilih dari 50 bahan pakan yang telah ditentukan/ tersedia.

b. Mengisi kromosom dengan membangkitkan bilangan integer secara acak antara 0-9. Setiap kromosom mewakili bahan pakan yang dipilih oleh user.

Pindah Silang (Crossover), Setelah proses pembangkitan populasi awal, proses selanjutnya yaitu reproduksi yang terdiri dari crossover dan mutasi. Individu-individu dari hasil pembangkitan populasi akan dipilih secara acak sebagai induk untuk dilakukan proses crossover. Dalam tahap ini harus ditentukan tingkat crossover rate $(\mathrm{Pc})$ untuk menyatakan banyaknya offspring yang dihasilkan. Pada laporan skripsi ini proses crossover menggunakan metode one-cut point dengan langkah-langkah berikut :

1. Menghitung jumlah offspring yang akan dihasilkan yaitu tergantung dari besarnya Pc dikalikan jumlah populasi (popsize).
2. Memilih dua induk secara acak tergantung dengan banyaknya offspring. Karena setiap satu kali proses crossover menghasilkan dua anak (child) dan satu kali proses crossover menyilangkan dua induk.

3. Memilih satu titik potong (cut point) secara acak dan menukarkan kromosom parent 1 bagian kanan cut point dengan kromosom parent 2 bagian kanan cut point untuk menghasilkan offspring

Mutasi, proses reproduksi selanjutnya yaitu proses mutasi. Peluang individu mengalami mutasi berdasarkan nilai $\mathrm{Pm}$ yang telah ditentukan terhadap jumlah keseluruhan gen hasil generate populasi. Pada laporan skripsi ini proses mutasi menggunakan metode reciprocal exchange mutation dengan langkah-langkah berikut :

1. Menghitung jumlah offspring yang akan dihasilkan yaitu tergantung dari besarnya Pm dikalikan jumlah populasi (popsize).

2. Memilih satu induk secara acak tergantung dengan banyaknya offspring. Karena setiap satu kali proses mutasi menghasilkan satu anak (child).

3. Memilih dua indeks untuk dijadikan mutation point (exchange point / XP) secara random kemudian menukarkan nilai pada indeks yang terpilih sebagai mutation point.

Perhitungan Fitness, Setelah didapatkan child hasil dari crossover dan mutasi, selanjutnya adalah melakukan perhitungan fitness untuk semua individu. Hasil perhitungan fitness kemudian akan dijadikan masukan proses seleksi. Seleksi Roulette Wheel, proses seleksi dilakukan untuk memilih individu dari himpunan populasi dan offspring yang dipertahankan hidup pada generasi berikutnya. Semakin besar nilai fitness sebuah chromosome maka semakin besar peluangnya untuk terpilih. Hal ini dilakukan agar terbentuk generasi berikutnya yang lebih baik dari generasi sekarang.

Metode seleksi yang sering digunakan adalah Roulette Wheel, pendekatan ini dilakukan dengan menghitung nilai probabilitas seleksi (prob) tiap individu berdasarkan nilai fitnessnya. Dari nilai prob ini bisa dihitung probabilitas kumulatif (probCum) yang digunakan pada proses seleksi tiap individu. Langkah-langkah membentuk Roulette wheel berdasarkan probabilitas kumulatif adalah (Firdaus. 2013) :

1. Misalkan fitness $\left(\mathrm{P}_{\mathrm{k}}\right)$ adalah nilai fitness individu ke-k digunakan untuk menghitung total fitnes. 
totalFitness $=\sum_{k=1}^{\text {popsize }=1}$ fitness $\left(P_{k}\right)$

2. Menghitung nilai probabilitas seleksi (prob) tiap individu,

prob $_{k}=\frac{\text { fitness }\left(P_{k}\right)}{\text { totalfitness }} \quad, \mathrm{k}=1,2,3, .$. popsize

3. Menghitung nilai probabilitas kumulatif (probCum) tiap individu,

$\operatorname{probCum}_{k}=\sum_{j=1}^{k} \operatorname{prob}_{j}, \mathrm{k}=1,2,3, \ldots$ popsize

4. Menghitung nilai fitness,

Fitness $=\frac{100}{(\text { harga }+(\text { kekurangan nutrisi } * K))}$

Memutar Roulette wheel untuk memilih setiap individu dengan langkah-langkah berikut:

$>$ Membangkitkan $r$ bilangan random pada range $[0,1]$.

Memilih / cek nilai k mulai dari 1 sampai popsize sehingga $\mathrm{r} \leq$ probCum $_{\mathrm{k}}$.

Setelah didapatkan individu populasi baru, selanjutnya adalah menentukan individu terbaik sebanyak jumlah populasi awal. Dengan mekanisme Roulette wheel maka individu dengan fitness lebih besar akan mempunyai peluang lebih besar untuk terpilih. Karena berupa peluang maka tidak menjamin bahwa individu yang memiliki fitness lebih besar akan selalu terpilih untuk masuk pada generasi berikutnya.

> Iterasi berhenti setelah $\mathrm{t}$ satuan waktu tercapai.

Skenario Pengujian, pada pengujian ini dilakukan untuk mendapatkan nilai parameter yang paling tepat untuk digunakan pada algoritme genetika agar solusi yang dihasilkan mampu mencapai titik optimal terbaik. Masing-masing pengujian dilakukan percobaan sebanyak 10 kali yang kemudian dihitung rata-rata fitness yang didapatkan untuk dianalisis. Bahan pakan yang digunakan sebanyak 5 yaitu bunkil kacang tanah, daun pisang, konsentrat broiler, minyak kelapa dan tepung daging.

\section{HASIL DAN PEMBAHASAN}

Hasil yang didapatkan dari proses interpretasi penerapan algorima genetika menggunakan metode roulette wheel pada penentuan optimasi komposisi bahan pakan ayam broiler dengan inputan popsize $=400, \mathrm{pc}=0.1, \mathrm{pm}=0.8$, iterasi $=350$, bahan pakan yang dipilih bungkil kacang tanah, daun pisang, konsentrat broiler, minyak kelapa dan tepung daging sebagai berikut :

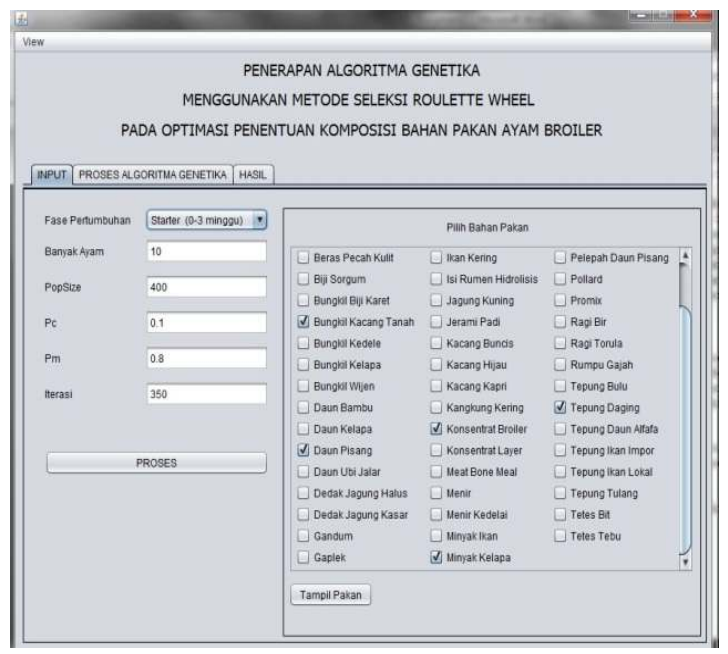

Gambar 2. Tampilan Halaman Awal

Terdapat 3 tab menu yaitu input, proses dan hasil.

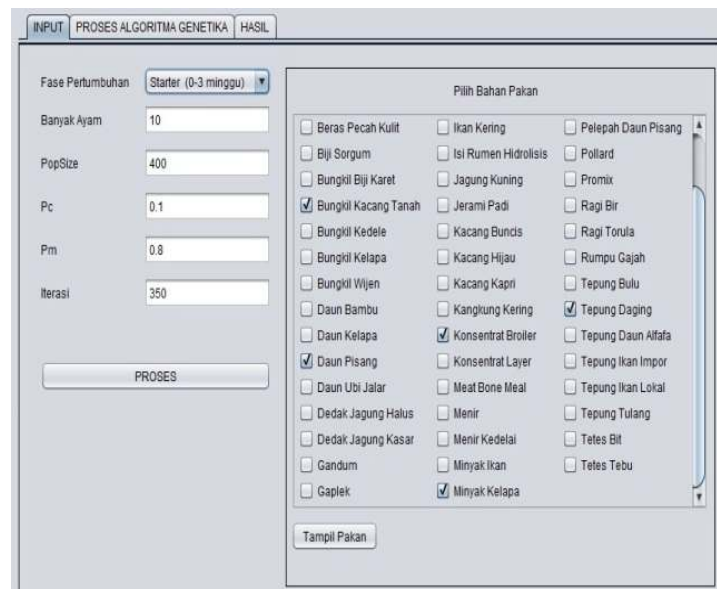

Gambar 3. Input Data

Setelah menginputkan data pada kolom yang disediakan maka tekan proses.

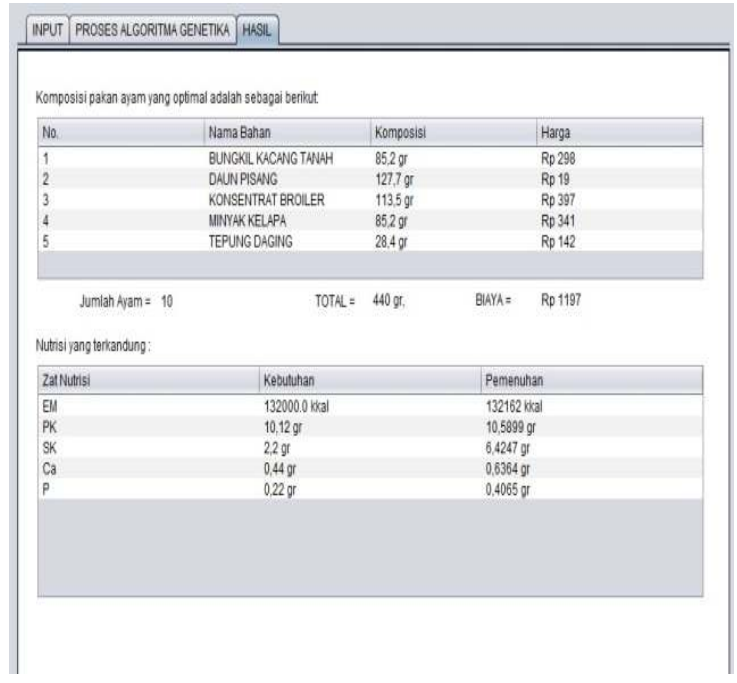

Gambar 4. Hasil 
Maka sistem akan menampilkan hasil dari inputan berupa biaya dan nutrisi.

Pada data yang diuji diatas merupakan data inputan yang telah mengalami pengujian sebanyak 10 kali diantarannya ialah :

1) Pengujian ukuran populasi digunakan untuk menentukan ukuran populasi yang terbaik untuk menghasilkan solusi terbaik dalam kasus ini.

Jumlah populasi $\quad: 50-500$ (kelipatan 50)

Pc $\quad: 0.6$

$\mathrm{Pm} \quad: 0.4$

Jumlah generasi $\quad: 50$

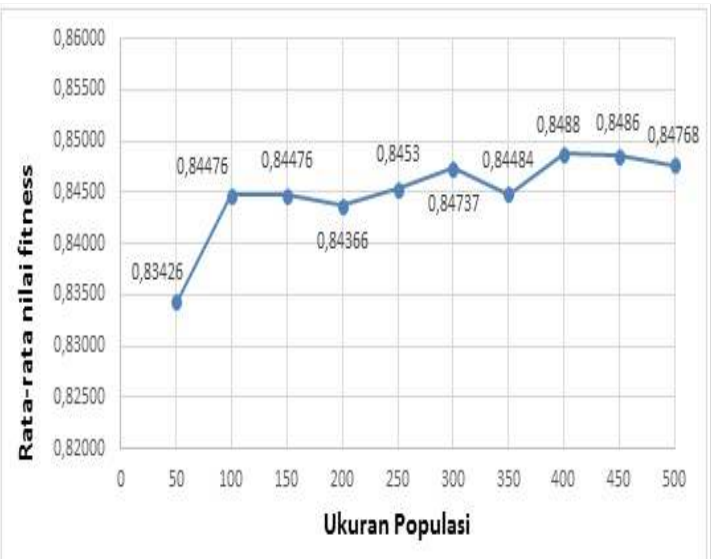

Gambar 5. Jumlah Populasi

Gambar diatas merupakan grafik hasil pengujian populasi terbaik dengan nilai 400 .

2) Pengujian banyak generasi digunakan untuk menentukan generasi yang terbaik untuk menghasilkan solusi terbaik dalam kasus ini.

Jumlah populasi : 400

Pc $\quad: 0.6$

$\mathrm{Pm} \quad: 0.4$

Jumlah generasi $\quad: 50-500$ (kelipatan 50)

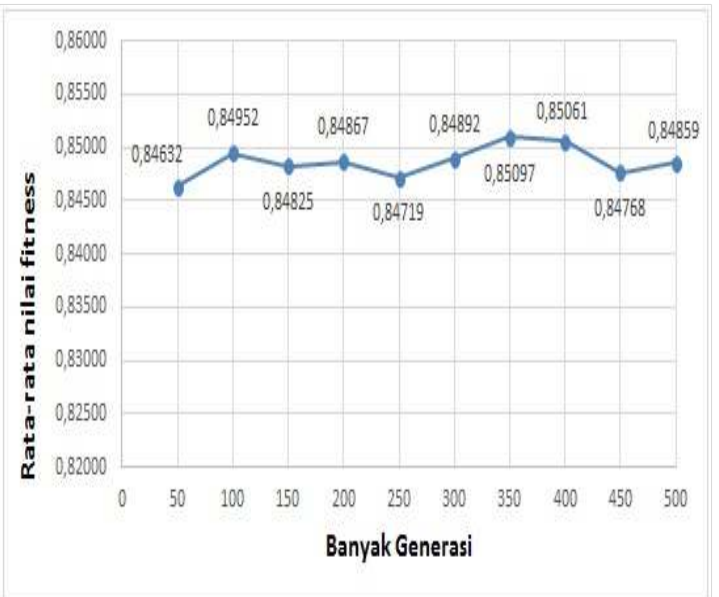

Gambar 6. Banyak Generasi
Gambar diatas merupakan hasil pengujian generasi terbaik dengan nilai 350 .

3) Pengujian kombinasi pc : pm digunakan untuk menentukan kombinasi yang terbaik untuk menghasilkan solusi terbaik dalam kasus ini.

$\begin{array}{ll}\text { Jumlah populasi } & : 400 \\ \text { Pc } & : 0-1 \\ \text { Pm } & : 0-1 \\ \text { Jumlah generasi } & : 350\end{array}$

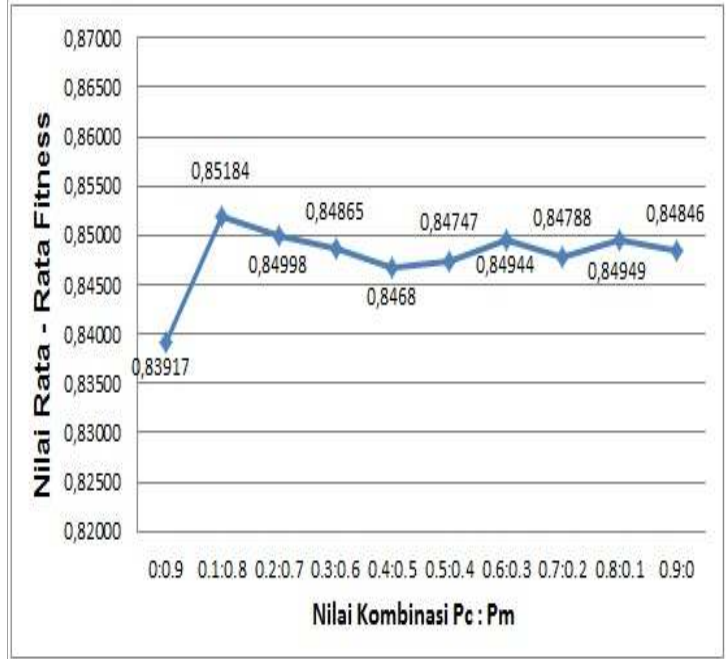

Gambar 7. Kombinasi Pc : Pm

Gambar diatas menunjukkan nilai kombinasi terbaik antara Pc dan Pm dengan nilai 0.1 : 0.8 .

\section{PENUTUP \\ Kesimpulan}

Berdasarkan uji coba parameter algoritma genetika dapat disimpulkan bahwa seluruh parameter sangat berpengaruh terhadap solusi yang akan dihasilkan. Pada hasil uji coba, dengan bahan pakan bungkil kacang tanah, daun pisang, konsentrat broiler, minyak kelapa dan tepung daging dengan parameter terbaik dengan rata - rata nilai fitness tertinggi dengan nilai Ukuran populasi $=400$ dengan fitness $0.8488, \mathrm{Pc}=0.1: \mathrm{Pm}=0.8$ dengan fitness 0.85184 , Banyak generasi $=350$ dengan fitness 0.85097 . Pada optimasi komposisi pakan ternak ini solusi yang diberikan oleh sistem merupakan perhitungan besarnya nilai fitness. Bila nilai fitness itu tinggi maka memiliki solusi paling optimal. Dikatakan optimal bila harga yang digunakan minimal dan kebutuhan nutrisi yang terpenuhi. 


\section{REFERENSI}

Andi, Romada Nugraha. 2011. "Optimalisasi Formulasi Pakan Ternak terhadap Ayam Pedaging dengan menggunakan Metode Linear Programming." Jakarta, Universitas Gunadarma.

Indrianingsih, Yuliani. 2010. "Algoritma Genetik Untuk Menyelesaikan Masalah Optimasi Fungsi Berkendala Dengan Pengkodean Bilangan Bulat." Sekolah Tinggi Teknologi Adisutjipto (STTA).

Firdaus, Wayan Mahmudy. 2013. "Algoritma Evolusi." Malang, Universitas Brawijaya Malang.

Amrullah. 2014. "Pentingnya Pemenuhan Kebutuhan Nutrisi pada Ayam Broiler." Jakarta Utara, Majalah Poultry.

Asfar, M. Syafar. 2014. "Ilmu Ransum Non Ruminansia/Unggas Kebutuhan Ransum Ayam Broiler Fase Starter Dan Finisher." Makassar, Universitas Hasanuddin.

Ariwibowo, Samuel Lukas, Martin Gunawan. 2008. "Penerapan Algoritma Genetika Pada Penentuan Komposisi Pakan Ayam Petelur." Tangerang, Universitas Pelita Harapan.

Basuki, Achmad. 2003. "Algoritma Genetika Suatu Altenatif Penyelesaian Permasalah Searching, Optimasi dan Machine Learning." Surabaya, Politeknik Elektronika Negeri Surabaya PENS-ITS.

Disnas Peternakan Provinsi Jawa Timur. 2016. "Data Bahan Pakan dan Nutrisi." http://disnak.jatimprov.go.id/fn_querynutri si.htm

Kusumadewi, Sri. 2004. "Pendahuluan Struktur Umum Komponen Utama Seleksi Rekombinasi Mutasi Algoritma Genetika Sederhana."

Marginingtyas, Ervina. 2015. "Penentuan Komposisi Pakan Ternak Untuk Memenuhi Kebutuhan Nutrisi Ayam Petelur Dengan Biaya Minimum Menggunakan Algoritma Genetika." Malang, Universitas Brawijaya.

Wijaya, Taruna P. 2010. "Analisa Ekonomi Pengaruh Penambahan Imbuhan Pakan (Bio Mos) Kedalam Semak Bunga Putih (Chromolaena ODORATA) Terhadap Broiler." Sumatra Utara, Universitas Sumatra Utara. 